\title{
Perancangan Aplikasi Layanan E-Konsultasi Akademik Kemahasiswaan Pada FakultasTeknologi Informasi Universitas Respati Indonesia
}

\author{
Melita Kusmadiani, Jenih, Tony Sugiarso \\ Fakultas Teknologi Informasi, Universitas Respati Indonesia \\ Melitakusmadiani6@gmail.com,jenih@fti.urindo.ac.,tonys \\ ugiarso@urindo.ac.id
}

\begin{abstract}
ABSTRAK
Saat ini layanan untuk konsultasi mahasiswa yang ada di fakultas teknologi informasi masih menggunakan pencatatan dan dilakukan dengan cara tatap muka, dimana cara ini memang efektif, tetapi belum ada monitoring, dan buku konsultasi yang tidak tersimpan dengan baik, sehingga perlu dibuatnya Aplikasi Layanan E-Konsultasi Akademik Kemahasiswaan Berbasis Website. Aplikasi tersebut untuk memonitoring dan mengevaluasi permasalahan mahasiswa dalam bimbingan akademik kemahasiswaan dalam konsultasi secara efektif dan efisen dengan pemanfaatan teknologi. Metode pengembangan sistem yang digunakan dalam pembuatan sistem ini adalah Model Waterfall. Aplikasi Sistem Layanan E-Konsultasi diharapkan mampu mencatat data konsultasi mahasiswa lebih akurat, tidak mudah rusak maupun hilang sehingga memberikan kinerja layanan yang baik seperti yang di harapkan.

Kata Kunci : e-konsultasi, akademik,layanan
\end{abstract}

\section{ABSTRACT}

Currently, the services for consulting students at the faculty of information technology still use recording and are carried out face-to-face, where this method is indeed effective, but there is no monitoring, and the consultation book is not stored properly, so it is necessary to make an EConsultation Service Application Website-Based Student Academics. The application is for monitoring and evaluating student problems in student academic guidance in effective and efficient consultation with the use of technology. The system development method used in making this system is the Waterfall Model. The E-Consultation Service System application is expected to be able to record student consultation data more accurately, not easily damaged or lost so as to provide good service performance as expected.

Keywords: e-consultation, academic, service 


\section{PENDAHULUAN}

Konsultasi dapat diartikan sebagai proses memberikan bantuan kepada seseorang oleh orang yang ahli dan memenuhi standar kualifikasi pada area tertentu untuk mengetahui tentang diri mereka, mengembangkan potensi, menyelesaikan masalah, membuat keputusan, Pendekatan diri, dan lain-lain.

Dengan adanya teknologi informasi membuat perubahan yang cukup berpengaruh dalam interaksi antara Mahasiswa dengan Dosen. Teknologi informasi tidakhanya sekedar menyediakan keterbukaan akses informasi atas pengetahuan mengenai dunia pendidikan akan tetapi juga hadir menjadi komplementer dari pelayanan kovensional lainnya.

Pada awalnya proses konsultasi mahasiswa dengan dosen dilakukan dengan cara tatap muka, dimana cara ini memang efektif,tetapi belum ada monitoring, dan buku konsultasi yang tidak tersimpan dengan rapih sehingga mudah hilang.

Berawal dari sini, dibuatlah sistem aplikasi berbasis web yaitu sistem konsultasi pembimbing akademik kemahasiswaan online, untuk membantu mahasiswa dalam melakukan konsultasi permasalahan pengaduannya.

Berdasarkan Latar Belakang, maka rumusan permasalahan dalam penelitian ini adalah bagaimana memonitor dan mengevaluasi proses konsultasi serta membuat sistem informasi konsultasi bimbingan akademik berbasis website di Fakultas Teknologi Informasi.

Berdasarkan dari perumusan masalah, maka tujuan penelitian ini adalah sebagai berikut : a. Menghasilkan sistem layanan konsultasi akademik kemahasiswaan yang dapat memberikan kemudahan dalam konsultasi permasalahan mahasiswa terhadap dosen yang bersangkut.

b. Untuk meningkatkan kinerja layanan dalam perkuliahan

\section{METODE}

Pendekatan penelitian dilakukan menggunakan pendekatan kualitatif dengan mengadakan metode pengamatan terlebih dahulu untuk memperoleh data dan dokumen yang di butuhkan untuk dapat merancang e-konsultasi mahasiswa di prodi sistem informasi. Proses membuat aplikasi menggunakan metode System Development Life Cyle (SDLC) model Waterfall.

Menjelaskan metode pengembangan sistem yang sering digunakan dalam tahapan pengembangan sistem yaitu model SDLC air terjun (Waterfall) sering juga disebut model sekuensial atau alur hidup klasik (classic life cycle). Berikut adalah gambar IlustrasiModel Waterfall pada gambar :

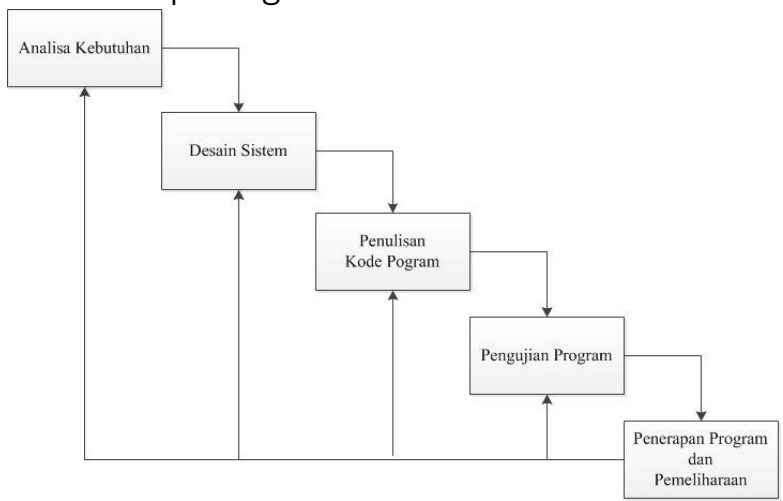

Gambar 1. Model Waterfall

Menspesifikasikan kebutuhan perangkat lunak agar dipahami perangkat lunak sepertiapa yang dibutuhkan oleh user.

a. Analisis dilakukan untuk melihatsituasi di Fakultas Teknologi Informasi dan kebutuhan kebutuhan sistem layanan konsultasi pada dosen-mahasisw 
b. Desain

Desain perangkat lunak adalah proses multi langkah yang fokus pada desain pembuatan program perangkat lunak termasuk struktur data, arsitektur perangkat lunak, representasi antarmuka, dan prosedur pengodean pada aplikasi layanan e-konsutasi.

c. Pembuatan kode program

Desain harus ditranslasikan kedalam program perangkat lunak. Hasil dari tahap ini adalah program komputer sesuai dengan desain yang telah dibuat pada tahap desain aplikasi layanan e-konsutasi.

d. Pengujian

Pengujian fokus pada perangkatlunak secara dari segi logika dan fungsional dan memastikan bahwa semua bagian sudah diuji pada aplikasi layanan e-konsutasi.

e. Pendukung (support) atau pemeliharaan (maintenance)

Pada tahap pendukung atau pemeliharaan dapat mengulangi proses di pengembangan mulai dari analisis spesifikasi untuk perubahan perangkat lunak yang sudah ada tapi tidak untuk membuat perangkat lunak yang baru pada aplikasi layanan e-konsutasi.

\section{HASIL DAN PEMBAHASAN}

Bimbingan akademik kemahasiswaan adalah kegiatan yang dilakukan oleh mahasiswa Universitas Respati Indonesia yang menyampaikan permasalahannya kepada dosen pembimbing masih menggunakan sistem manual dengan cara :

a. Setiap akan konsultasi masih pencatatan/menulis pada buku konsultasi. b. Data konsultasi mahasiswa masih menggunakan buku catatan konsultasi.

Adapun Kendala yang dihadapi Staff Prodi dalam konsultasi mahasiswa yaitu pencatatan konsultasi masih menggunakan buku konsultasi sehingga mudah hilang ataupun rusak.

\section{Solusi Permasalahan}

Berdasarkan analisa yang dilakukan belum dapat diimplementasikan secara efisien sehingga memberikan solusi pemecahan masalah dengan cara :

a. Perlu dibangunnya aplikasi layanan ekonsultasi akademik kemahasiswaanagar data konsultasi dikelola denganmaksimal.

b. Mencatatan data konsultasi lebih akurat dengan adanya bukti file.

Flow Of Document

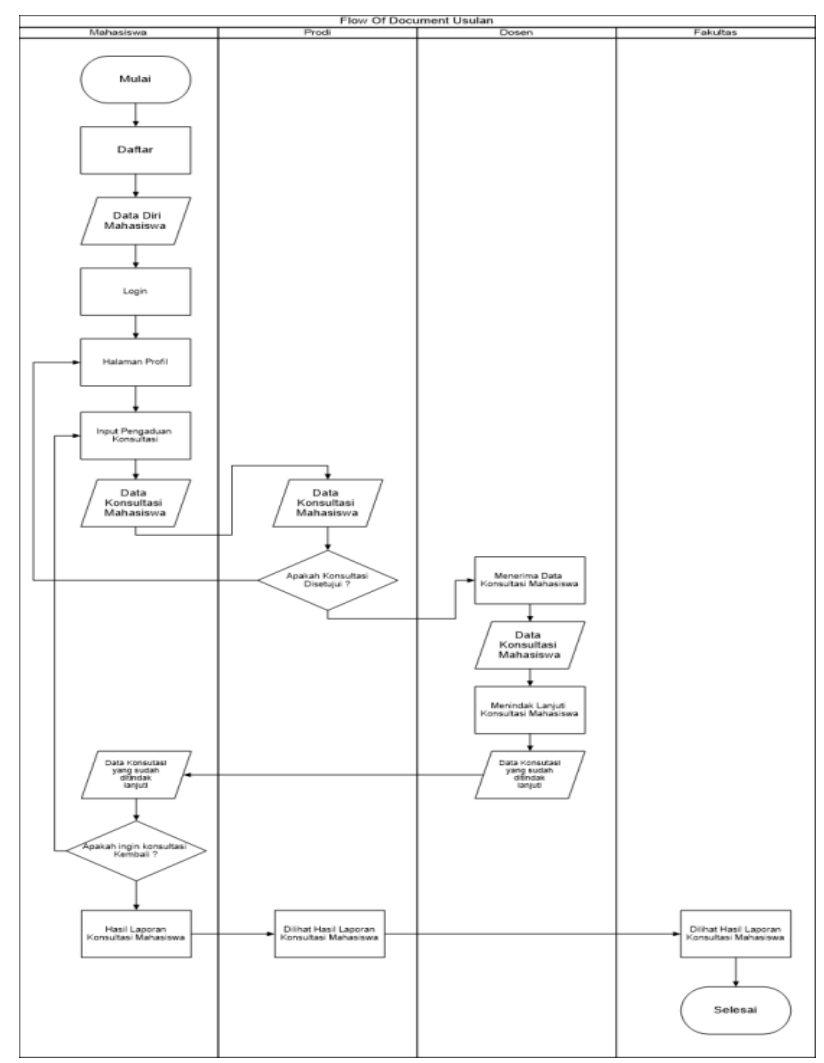

Gambar 2. flow of document sistem E-konsultasi yang sedang berjalan 


\section{Diagram Konteks}

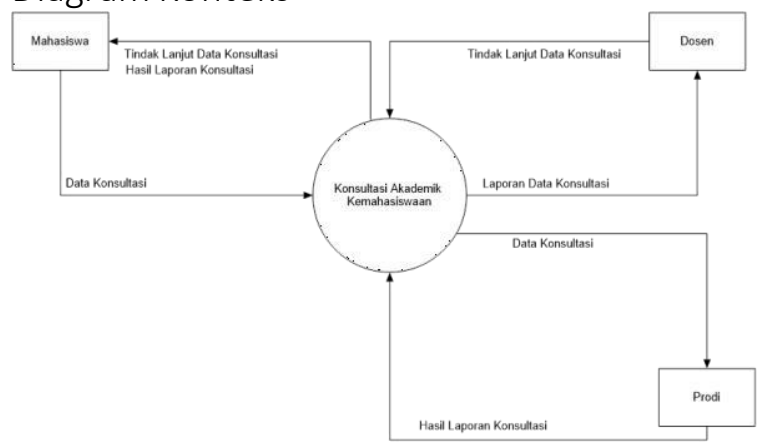

Gambar 3. Diagram Konteks Sistem yang sedang berjalan

Diagram Nol

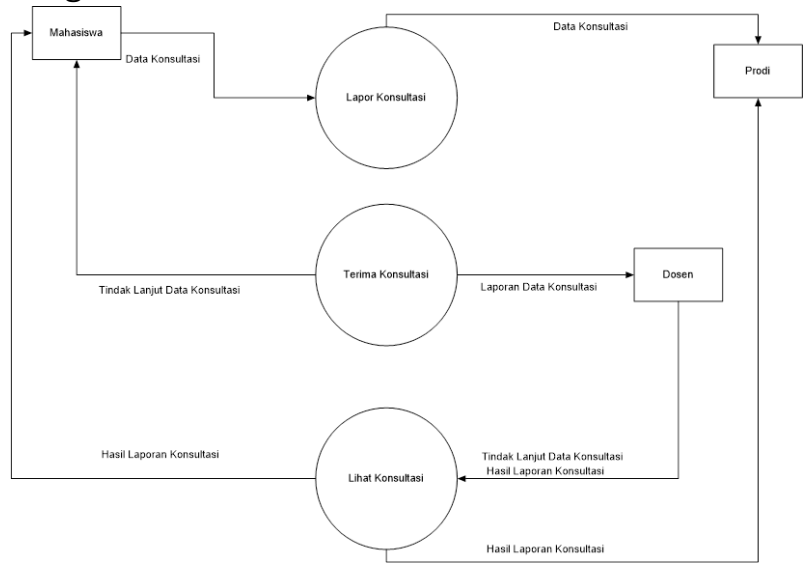

Gambar 4. Diagram Nol Sistem yang sedang berjalan

Tampilan Halaman Utama

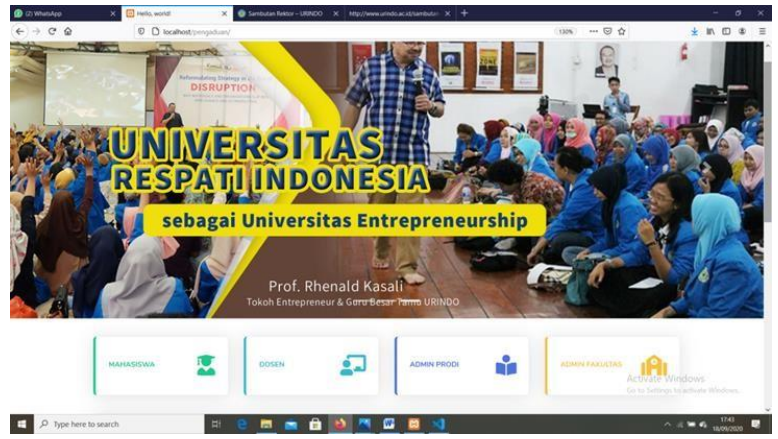

Gambar 5. Tampilan Halaman Utama

Tampilan halaman utama merupakantampilan yang

pertama kali

muncul ketika sistem pendukung keputusandiakses.
Tampilan Halaman Login

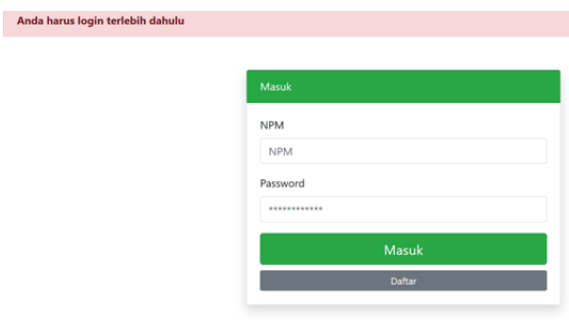

Gambar 6. Tampilan Halaman Login

Tampilan halaman login berfungsi untuk melakukan login sistem bagi mahasiswa, dosen, prodi, dan fakultas dengan cara mengetikkan username dan password pada kotak login pada halaman login.

Tampilan Profil Mahasiswa

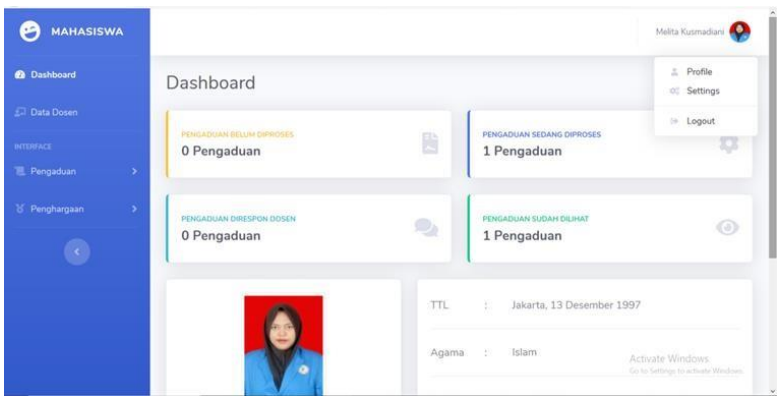

Gambar 7. Tampilan Profil Mahasiswa

Tampilan halaman Profil merupakan tampilan dari data profil.

Tampilan Halaman Input Pengaduan Mahasiswa

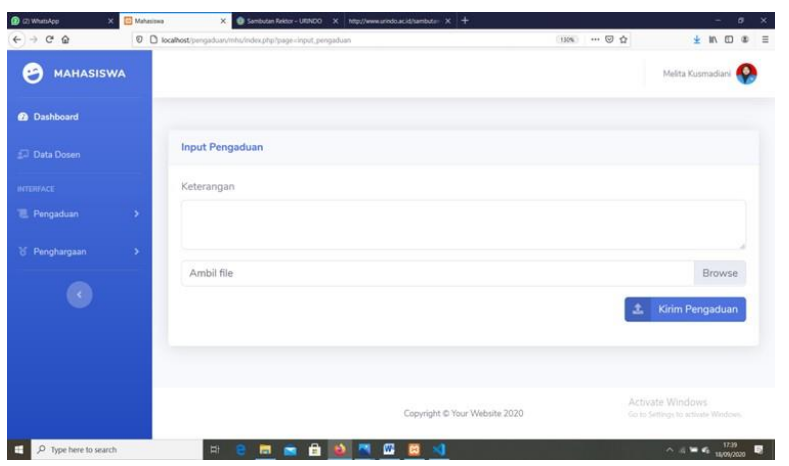

http://ejournal.urindo.ac.id/index.php/TI 
Gambar 8. Tampilan Halaman Input Pengaduan Mahaiswa

Halaman Pengaduan mahasiswa berfungsi untuk menginput pengaduan mahasiswa dan memilih dosen yang bersangkutan.

Tampilan Halaman Data Konsultasi

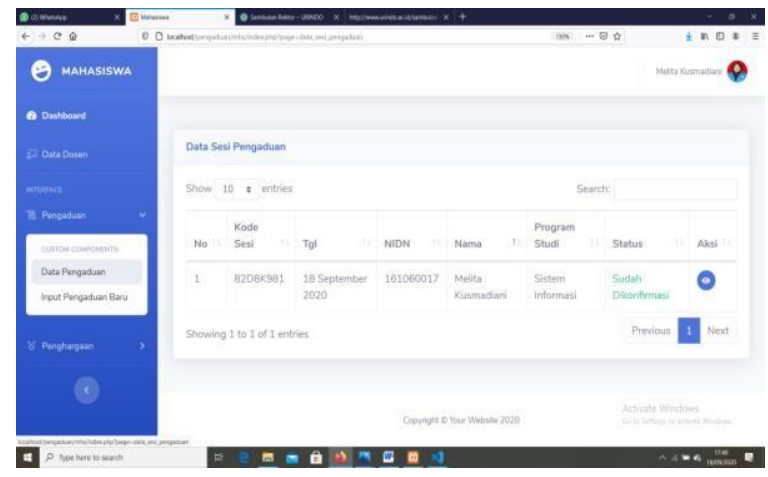

Gambar 9. Tampilan Halaman Data Konsultasi Tampilan data konsultasi hanya menampilkan data konsultasi mahasiswa.

Tampilan Halaman Detail Hasil Pengaduan

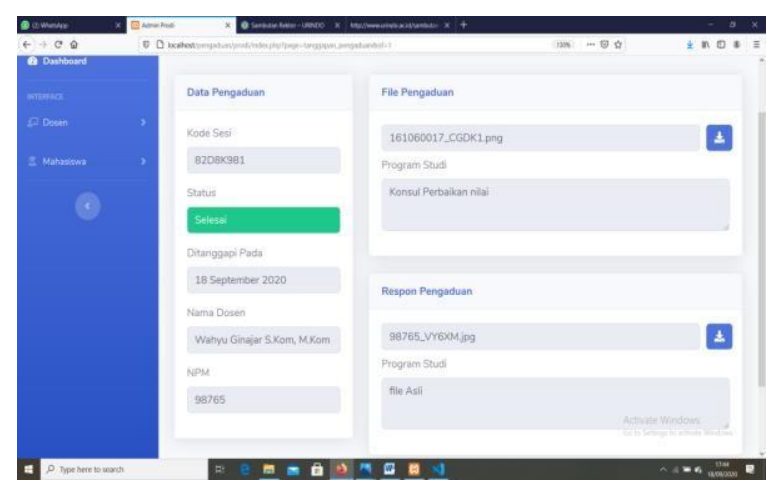

Gambar 10. Tampilan Halaman Detail Hasil Pengaduan

Tampilan data bimbingan hanya menampilkan data pengaduan yang dilihat oleh Prodi Maupun Fakultas.
Tampilan Halaman Tindak Lanjut pada Dosen

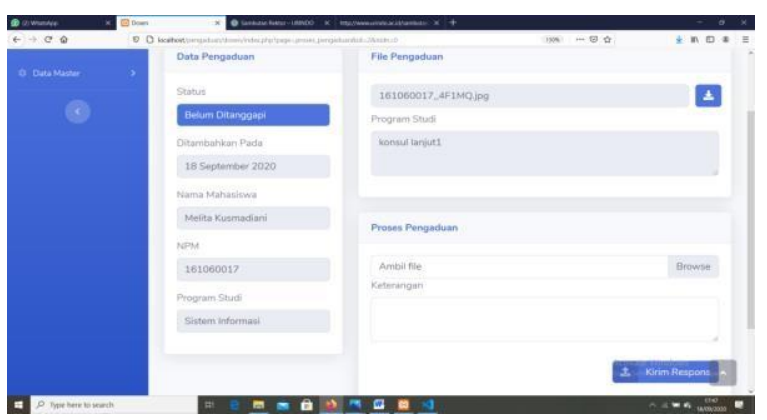

Gambar 11. Tampilan Halaman Tindak Lanjut pada Dosen

Tampilan Halaman Tindak Lanjut hanya menampilkan Tindakan lanjutan pengaduan yang dilakukan oleh dosen dengan mahasiswa.

\section{SIMPULAN}

Dengan adanya sistem layanan E- Konsultasi Akademik Kemahasiswaanberbasis web maka pengarsipan lebih rapih dan kegiatan konsultasi mahasiswa lebih efektif walaupun tidak bertatap muka secara langsung.

\section{DAFTAR PUSTAKA}

[1] Absurrasyid, Efy Yosrita. Fikri Amarullah. Sistem E-Konseling web upaya meningkatkan kualitas bimbingan akademik kemahasiswaan. Jurnal IImiah FIFO, STT PLN, Jakarta.

[2] Ary Budi Warsito, Untung Rahardja. Dwi Maya Suningsih. Pengembangan konsultasi sebagai monitoring pelayanan dosen dan mahasiswa. STMIK Rahardja, 14 Juni, Jakarta.

[3] Azhar ohi, Yusi Tyroni dan Djoko Pramono. Pengembangan Sistem Informasi Penjadwalan Tatap Muka dan Konsultasi Mahasiswa dengan Dosen Fakultas Teknologi Informasi Universitas 
Brawijaya. Jurnal Pengembangan Teknologi Informasi dan Ilmu Komputer. Vol.3,No.6. juni 2019, hlm.5565-5572

[4] Doni Adriyansyah. 2017. Aplikasi Penerimaan Mahasiswa Baru Online Dengan PHP dan BOOTSTRAP. CV ASFA Solution, Software Development, IT \& Publishing, Cirebon.

[5] Drs.Tri Rsma. 2015. Kamus Lengkap Bahasa Indonesia. Karya Agung, Surabaya.

[6]Fathansyah, Freddy. 2015. Basis Data Revisi kedua. Informatika Bandung, JawaBarat.

[7] Hartono, Jogiyanto. 2005. Analisa dan Desain Sistem Informasi : Pendekatan Terstruktur Teori dan Aplikasi Bisnis. Andi, Yogyakarta.

[8] Ir.Harianto. 1993. Konsep Dan Perancangan Database. Andi Offsety.Yogyakarta
[9] Nugroho, Adi Sulistyo. 2015. Analisis dan perancangan Sistem Informasi. Trans Tekno, Yogyakarta.

[10] Sri Handayaningsih, Wahyudi Pujianto. Sistem Konsultasi Dan Laporan Pembimbing Tugas Akhir. Seminar nasional Informatika 2010. UPN "Veteran" Yogjakarta, 22 Mei 2010

[11] Sutabri,Tata. 2012. Analisis Sistem Informasi. Andi, Yogyakarta.

[12] Sutristo, rahmawati. Dwi Maya Suningsih. Rancangan Sistem Informasi Konsultasin Akademik Mahasiswa Berbasis Web . STMIK PRASTIKOM, Tanggerang. 